\title{
Study on the Existence Form of Hydroxyl Groups in Coals - Reactivity of Chromic Oxide Ion with Hydroxyl Groups in Coals -
}

\author{
Shigeki FuruKawA, Masaki OKADA, Satoshi HARADA, and Yohichi SuZUKI \\ (Received March 11, 2003)
}

\author{
石炭中に含まれる水酸基の存在形態に関する研究 \\ 一石炭中の水酸基に対するクロム酸イオンの反応性一 \\ 古川茂樹，岡田昌樹，原田 聡，鈴木庸一
}

\begin{abstract}
The reaction of chromic oxide ion in aqueous solution with twelve kinds of coal samples has been studied. It was found that the chromic oxide ion reacted selectively to catechol type compounds at $273 \mathrm{~K}$ by the experimental result for some kinds of coal model chemical compounds. The existence ratio of catechol type components in each coals was estimated at $273 \mathrm{~K}$.
\end{abstract}

\section{Key Words}

Coal, Chromic anhydride, IR spectrum, Phenolic hydroxy group, Catechol type phenols

\section{1. 緒 言}

石炭の構造に関する研究は, Krevelen 以降今日まで盛んに 行われており，このことは未だに石炭構造は複雑で不明瞭な 部分が多く, また化学的分析が困難な対象であることを示唆 している ${ }^{1 \sim 8}$ 。石炭中の官能基の定量に関しても同様であり， 現在でも主として化学分析に頼らざるを得ないのが現状であ ろう。フェノールに代表される水酸基は石炭中に含まれる官 能基の中でも主要なものの一つであり，水素結合による石炭 分子同士の非共有結合ネットワークに寄与するなど，石炭構 造を決定する大きな要因の一つとなっている。近年 Shinnの 石炭構造モデル 3) P Marzec ら ${ }^{7)}$ に代表されるように, 石炭中 の各分子は予想ほど大分子量を持たず，2４ 環程度の芳香 族縮合環を単位ユニットとし，そのユニットがメチレン鎖あ るいはエーテル結合により $1 \sim 3$ 程度結合しあった程度の分 子が，互いに非共有結合によりネットワークを形成し，見か け上大分子様を呈すると考えられている。石炭構造を理解す る上で非共有結合を把握することはきわめて重要である。近 年，その一翼を担う水素結合に寄与する水酸基やカルボキシ ル基等含酸素官能基の定性，定量に関する報告，あるいは石 炭中の水素結合分布に関する研究が多数行われている ${ }^{9)}$ 16)。 しかしながら石炭中の水酸基の存在状態を直接測定した研究 事例は比較的少ないと思われる。

著者らはクロム酸水溶液に石炭粉末を添加すると, 石炭は

Department of Applied Molecular Chemistry,

College of Industrial Technology, Nihon University

1-2-1 Izumi-cho, Narashino, Chiba 275-8575, Japan
クロム酸イオンと反応 (あるいは吸着) し, 水中に溶解して いるクロム酸イオンを効率良く分離できることを報告してい る ${ }^{17)}$ こここで生じる反応は, 一般に考えられるようなクロム 酸による酸化反応ではなく, ジョーンズ酸化過程で生じるよ うなクロム酸エステル形成プロセスで終結しているものと思 われ, クロム酸イオンは主として石炭中の水酸基と化学的に 反応しているものと考えられる。この特性を利用すれば排水 中のクロム酸イオンの除去にも応用が可能となる。さらに反 応したクロム酸イオンは, 石炭の水素化分解触媒として機能 するため, 未利用資源, あるいは廃棄物の有効利用技術とし て期待される。ところがクロム酸イオンとの反応性は石炭の 種類によって大きく異なる。これまでの検討結果からクロム 酸イオンと石炭との反応は, 石炭中の水酸基に由来するもの と考えられ, 水中で単に両者を混合するだけで, 水酸基量に 対応した反応量を示すのであれば，非常に簡便な水酸基の定 量法として期待できる。しかしながら周知の通り石炭にはさ まざまな種類が存在し, その組成や構造, 物性等も異なる。言 い換えれば石炭の種類が変われば，水酸基量だけでなくすべ ての状態が変化するといっても過言ではないだろう。本系の ように固一液間の相互作用においては固体 (石炭) 表面の状 態が強く影響する。とりわけ石炭はその表面上に多くの細孔 を有することが知られている。こうした環境でクロム酸イオ ンは, 石炭中の水酸基に対して化学的に反応するだけでなく

日本大学 生産工学部応用分子化学科

于 275-8575 千葉県習志野市泉町 1-2-1 
(化学吸着), 物理吸着する可能性も有する。すなわち石炭に 対するクロム酸イオンの反応量が種々の石炭中に存在する水 酸基量に対応することを確認しなければならない。これまで は比較的水酸基を多く含むと予想される中山亜炭を試料とし て検討を行ってきたが17), 本報告では石炭化度の異なる 12 種 類の石炭に対しク口ム酸を作用させ, その反応量とその際に 生じるIRスペクトル上の変化との相関, あるいはアセチル化 法により測定した石炭中の水酸基量との相関について評価し た。これらの結果に基づき石炭中の水酸基の存在状態に関す る知見を得ることを目的とした。

\section{2. 実 験}

\section{1 石炭および試薬}

石炭化度の異なる12種類の石炭を用いた。また石炭中の灰 分が $\mathrm{CrO}_{3}$ 水溶液中に一部溶解することと, カオリナイトの赤 外線吸収スペクトルが $900 \sim 1000 \mathrm{~cm}^{-1}$ 付近に現われるため脱 灰処理したものを試料とした。脱灰処理は, 三浦ら ${ }^{18)}$ の方法 を用いて行った。各種石炭の元素分析值および脱灰率をTable 1 に示した。無水クロム酸, フェノール, 2 -ナフトール, カ テコール，。-クレゾール，2，6-ジメチルフェノール， ベ ンジルアルコール，3，4-ジヒドロキシトルエン， 3,4-ジ ヒドロキシ安息香酸， $2 ， 6$ - ジヒドロキシアセトフェノン, 1, 2-ジヒドロキシアントラキノン(アリザリン), 1, 2, 4トリヒドロキシアントラキノン(プルプリン), ピロガロール は市販特級品を使用した。

\section{$2.2 \mathrm{CrO}_{3}$ 反応物の調製}

\subsection{1 フェノール類一 $\mathrm{CrO}_{3}$ 反応物の調製}

各種フェノール類 $(0.01 \mathrm{~mol})$ を $50 \mathrm{ml}$ の水に溶解し, 温浴中 で323K（あるいは273K）に保ち，所定の温度，濃度に調製 した $\mathrm{CrO}_{3}$ 水溶液 $50 \mathrm{ml}$ を攪拌しながら徐々に加え， 2 時間反 応させた。 $\mathrm{CrO}_{3}$ 水溶液を加えると同時に反応が進行し, 黒色 あるいは褐色の沈殿が生成した。反応終了後, 万別し, $\mathrm{CrO}_{3}$ による色がなくなるまで水洗し, 隇圧乾燥したものをフェ
ノール類一 $\mathrm{CrO}_{3}$ 反応物とした。 $\mathrm{CrO}_{3}$ の反応量はルツボに一定 量の反応物を精秤し, 電気炉中, $800^{\circ} \mathrm{C}$ で 2 時間焼成させ 6 価 の $\mathrm{CrO}_{3}$ を完全に 3 価の $\mathrm{Cr}_{2} \mathrm{O}_{3}$ に変え, その残留量から $\mathrm{CrO}_{3}$ 量 に換算し, 試料の仕込量中に存在する $\mathrm{CrO}_{3}$ 量を算出した ${ }^{19)}$ 。

\subsection{2 $\mathrm{CrO}_{3}$ 反応炭の調製}

$60 \mathrm{mesh}$ 以下に粉砕した石炭 $2 \mathrm{~g}$ を $50 \mathrm{ml}$ の水中に分散させ, 温浴中で $323 \mathrm{~K}$ (あるいは $273 \mathrm{~K}$ ) に保ち, 所定の温度, 濃度 に調製した $\mathrm{CrO}_{3}$ 水溶液 $50 \mathrm{ml}$ を攪拌しながら徐々に加え， 2 時間反応させた。反応終了後, 反応炭をろ別し, 洗液に $\mathrm{CrO}_{3}$ による色がなくなるまで水洗し, 減圧乾燥したものを $\mathrm{CrO}_{3}$ 反 応炭とした。 $\mathrm{CrO}_{3}$ の反応量はフェノール類の場合と同様に燃 焼法により算出した。

\section{3 赤外線吸収スペクトルの測定}

各種試料のIRスペクトルは錠剤成型法および拡散反射法に より測定した。錠剤成型法については，島津製作所社製FT-IR 8200A（測定条件：分解能； $2 \mathrm{~cm}^{-1}$, 積算回数；100）を使用 し, 拡散反射法についてはBIO-RAD 社製PTS-60A，および拡 散反射測定装置（BIO-RAD 社製 HY-9003-1MTN）を使用して 測定した。（測定条件：分解能； $2 \mathrm{~cm}^{-1}$, 積算回数; 32) 詳細 は前報と同様に行った ${ }^{17)}$ 。

\section{4 化学的手法による石炭中の水酸基の定量（アセチル化} 法）

アセチル化による石炭中の水酸基の定量は畑見らの方法を 用いて行った ${ }^{20)}$ 。石炭試料 $0.6 \mathrm{~g}$ を容量 $200 \mathrm{ml}$ の三角フラスコ に採取し, 無水酢酸一ピリジン (1:2) 混合溶液 $20 \mathrm{ml}$ を加 え, 防湿管付きジムロートを取り付けた。ホットプレート上 で混合溶液がわずかに沸騰する程度で約20時間加熱し, 石炭 中の水酸基をアセチル化した。

$\mathrm{Coal}-\mathrm{OH}+\left(\mathrm{CH}_{3} \mathrm{CO}\right)_{2} \mathrm{O} \rightarrow \mathrm{Coal}-\mathrm{O}-\mathrm{COCH}_{3}+\mathrm{CH}_{3} \mathrm{COOH}$ 終了後, 冷却した反応液に水を加え, 全量を約 $200 \mathrm{ml}$ になる よう希釈し, 反応した石炭をろ別した。洗浄後, 減圧乾燥し

Table 1 Ultimate analysis of the coals

\begin{tabular}{|c|c|c|c|c|c|c|c|c|c|}
\hline \multirow{2}{*}{ Coals } & \multicolumn{5}{|c|}{ Ultimate analysis (wt\% d. a. f.) } & \multirow{2}{*}{$\begin{array}{c}\text { Ash } \\
\text { (wt\%) }\end{array}$} & \multicolumn{2}{|c|}{ Demineralized coal } & \multirow{2}{*}{$\begin{array}{l}\text { Reacted } \mathrm{CrO}_{3} \\
(\mathrm{~mol} / \mathrm{g}-\mathrm{coal})^{* * *}\end{array}$} \\
\hline & $\mathrm{C}$ & $\mathrm{H}$ & $\mathrm{O}^{*}$ & $\mathrm{~N}$ & $\mathrm{OH}^{* *}$ & & Ash residue & Demineralized rate (\%) & \\
\hline Nakayama & 63.0 & 4.5 & 31.4 & 1.1 & 8.7 & 12.9 & 0.20 & 98.5 & $1.47 \mathrm{E}-03$ \\
\hline Battleriver & 65.4 & 4.2 & 29.3 & 1.0 & 5.3 & 6.4 & 0.17 & 97.4 & $1.10 \mathrm{E}-03$ \\
\hline Wyoming & 66.8 & 4.5 & 27.8 & 0.8 & 8.3 & 6.3 & 0.14 & 97.8 & $1.12 \mathrm{E}-03$ \\
\hline Blair Athol & 67.7 & 4.3 & 26.8 & 1.1 & 7.9 & 10.7 & 0.14 & 98.7 & 8.97E-04 \\
\hline Taiheiyo & 70.7 & 6.1 & 22.2 & 1.1 & 6.5 & 16.3 & 1.65 & 89.9 & $7.60 \mathrm{E}-05$ \\
\hline Illinois No. 6 & 71.9 & 5.0 & 21.9 & 1.1 & 6.5 & 11.1 & 0.87 & 92.2 & $4.20 \mathrm{E}-04$ \\
\hline Medicine Bow & 73.5 & 4.1 & 21.6 & 0.8 & 5.8 & 5.0 & 0.36 & 92.9 & $1.52 \mathrm{E}-04$ \\
\hline Neijyoto & 74.1 & 4.5 & 20.4 & 1.0 & 5.0 & 10.4 & 0.55 & 94.7 & $1.65 \mathrm{E}-04$ \\
\hline Jiyowan & 75.6 & 3.8 & 19.8 & 0.7 & 4.6 & 4.0 & 0.79 & 80.2 & $7.14 \mathrm{E}-04$ \\
\hline Celehon & 78.2 & 5.2 & 15.0 & 1.5 & 4.4 & 1.0 & 0.32 & 69.2 & $3.94 \mathrm{E}-04$ \\
\hline Eveneza & 78.4 & 5.6 & 14.5 & 1.5 & 4.5 & 14.2 & 0.46 & 96.8 & $3.04 \mathrm{E}-04$ \\
\hline Sunny Side & 80.3 & 5.3 & 12.7 & 1.7 & 4.8 & 5.2 & 0.16 & 96.9 & $1.41 \mathrm{E}-04$ \\
\hline Paranbahan & 81.3 & 5.3 & 10.9 & 2.6 & 3.3 & 12.9 & 0.60 & 95.3 & $1.31 \mathrm{E}-04$ \\
\hline
\end{tabular}

* difference, ${ }^{* *}$ by the acetylation method, ${ }^{* * *}$ by the combustion method 
たものをアセチル化炭とした。得られたアセチル化炭 0.3 $0.5 \mathrm{~g}$ を精秤し, $200 \mathrm{ml}$ の三角フラスコに採取し, 数滴のメタ ノールを滴下して湿潤させ，水酸化バリウム 8 水和物 $2 \mathrm{~g}$ と 水40mlを加え，ジムロートを取り付けた。ホットプレートに より，溶液がわずかに沸騰する程度で 20 時間加熱し，アセチ ル基を加水分解した。

Coal-O-COCH$H_{3}+\mathrm{H}_{2} \mathrm{O} \rightarrow \mathrm{Coal}-\mathrm{OH}+\mathrm{CH}_{3} \mathrm{COOH}$

反応後溶液をろ別し，万液と洗液を合わせて $200 \mathrm{ml}$ となるよ うに調整した。その溶液からホールピペットを用いて $5 \mathrm{ml}$ 採取し，陽イオン交換樹脂を充填したカラム $(14 \mathrm{~mm} \phi \times$ 250mm)に $3 \sim 4 \mathrm{ml} / \mathrm{min}$ 程度の流速で通過させた。通過液中 の酢酸イオンをフェノールフタレインを指示薬として $0.1 \mathrm{M}$ 水 酸化ナトリウム水溶液により滴定し, 水酸基量とした。

\section{1 各種石炭と $\mathrm{CrO}_{3}$ の反応}

Table 1 に示した試料炭に対してクロム酸との反応を試み た。その結果を Fig. 1 に示す。前報で述べたように，石炭と クロム酸との反応量は石炭化度に依存し, 石炭化度の増加に 伴い直線的に減少する。ところがいくつかの石炭はこの傾向 から逸脱し，石炭化度が低くても反応しないものが存在する。 これらは後述するように, 石炭中の水酸基の存在状態や水酸 基の種類が異なるためと推察される。この結果から,ここで は便宜上，石炭とクロム酸との反応量が，石炭化度と逆比例 する関係を有する系列（系列 1) とそうではない系列（系列

2）に分けて考えることとした。

\section{$3.2 \mathrm{IR}$ スペクトルによる解析}

\subsection{1 クロム酸反応量と面積減少率との関係}

クロム酸と石炭が反応すると，石炭のIRスペクトル中 1100 〜 1300 $\mathrm{cm}^{-1}$ のC-O伸縮に帰属される波数領域が減少し，その

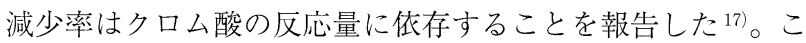

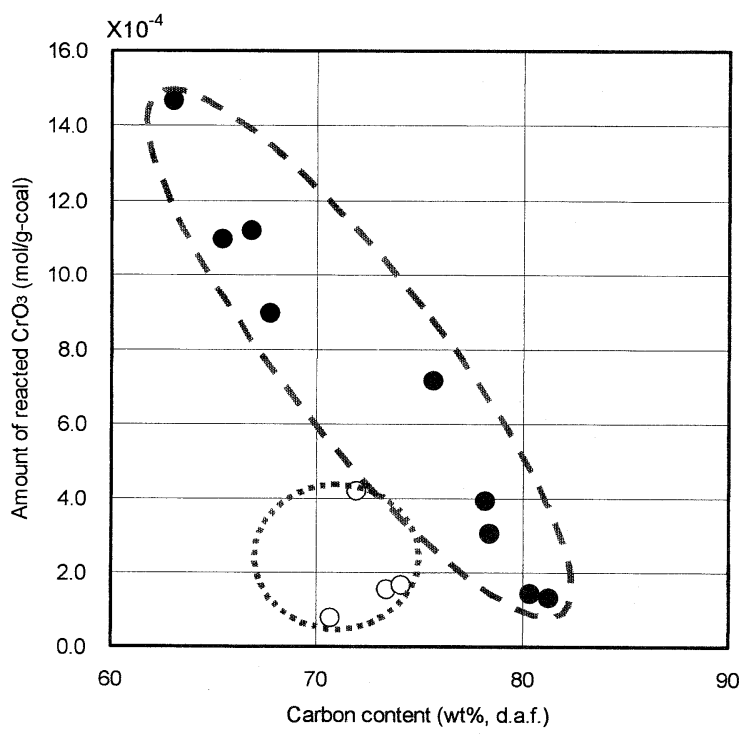

Fig. 1 Carbon content of coal vs. amount of reacted $\mathrm{CrO}_{3}$ (Closed circles denote first group coals, Open circles denote second group coals)
こでは今回使用した石炭に対し，同様の評価を試みた。各石 炭に対して最大の反応量となるように調製したクロム酸反応 炭のIRスペクトルを測定し，前報と同様の操作で面積減少率 を求めた。Fig. 2は各石炭に対する最大クロム酸反応量と面積 減少率の関係を示したものである。両者は比較的良好な直線 関係を示すことがわかる。しかもFig. 1で観測された，2 種類 の系列はほぼ一つの直線上にのることがわかった。ここで石 炭は天然物であり，その種類が変われば，組成はもとより表 面構造や官能基分布等すべてが異なると考えられる。しかし ながら，本結果は両者の間に明らかな相関関係を示した。つ まり今回用いたすべての石炭に対し，クロム酸は少なくとも 同様の作用をしていると考えることができ，そしてそれが主 反応であると考えられる。クロム酸イオンがフェノール等の 水酸基に対してのみ反応することを考慮すれば，主として石 炭中の水酸基とのみ反応すると評価して差し支えないのでは ないか，と考えられる。そして後述するように，系列 1 と 2 の石炭に対するク口ム酸の反応は本質的に同じであるが，石 炭中の水酸基はクロム酸と反応できるものとそうでないもの の，大きく 2 種類に大別されると推察される。

\subsection{2 石炭中の水酸基に対するクロム酸イオンの反応挙動} 石炭のIRスペクトルにおいてクロム酸イオンとの反応に伴 いC-O 伸縮振動に影響があらわれるとすれば，当然高波数領 域の O-H 伸縮振動にも何らかの影響が観測されると考えられ る。各脱灰炭とそれらにクロム酸が反応したときの水酸基の 挙動を IR スペクトルにて測定した。Fig. 3 に2000〜4000 $\mathrm{cm}^{-1}$ の領域における原炭と反応炭の差スペクトルを示した。 石炭種により形状は異なるものの, クロム酸の反応に伴い, $2000 \sim 2800 \mathrm{~cm}^{-1}$ の領域が減少し，3000〜 3600 $\mathrm{cm}^{-1}$ の領域が 増加した。三浦らの報告に基づき ${ }^{14)}$ ，前者はカルボキシル基 同士の会合に伴う水酸基の吸収帯と考えられ，後者は水酸基 同士の会合に伴う水酸基（アルコール，フェノール，水を含 む）の吸収帯と考えられる。また $3600 \mathrm{~cm}^{-1}$ 以上の領域は水素 結合を形成しないフリーな水酸基の領域である。この結果は,

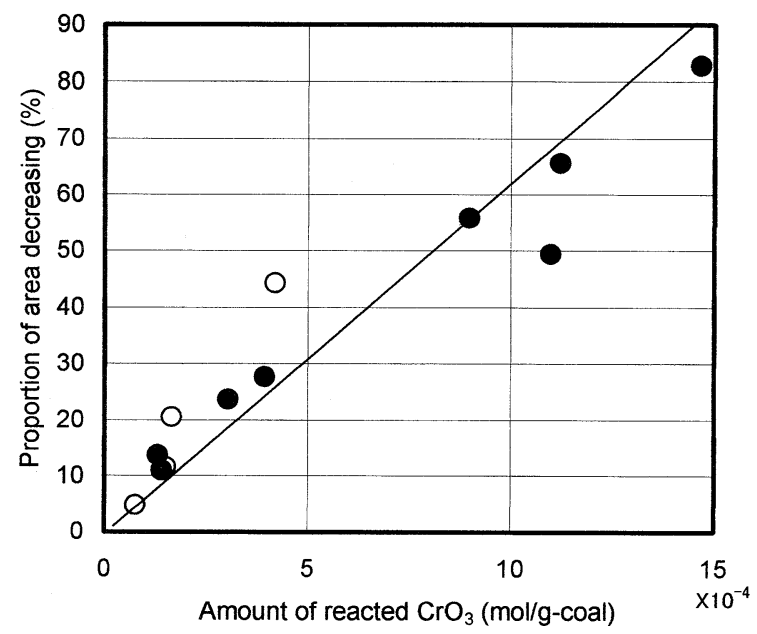

Fig. 2 Relationship between amount of reacted $\mathrm{CrO}_{3}$ and the proportion of area decreasing (Closed circles denote first group coals, Open circles denote second group coals) 


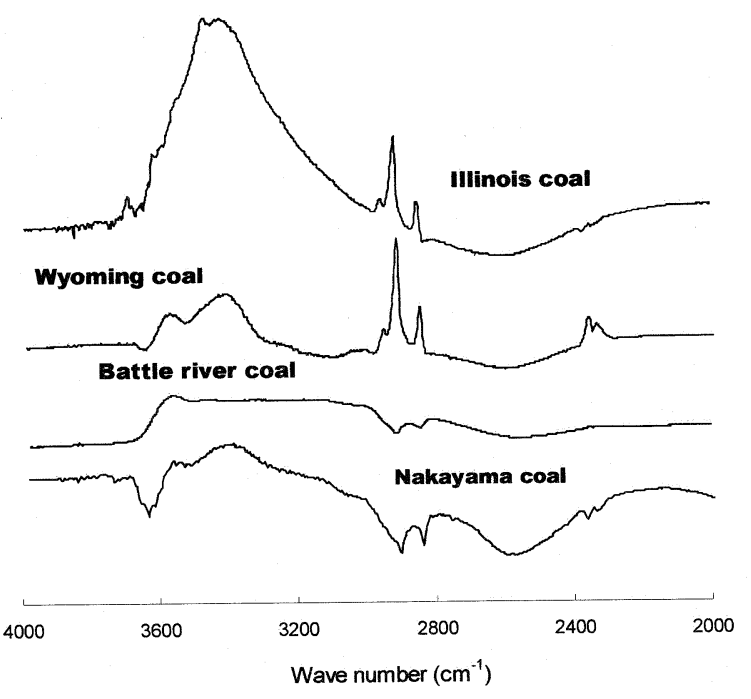

Fig. 3 Difference IR spectra of parent coal and $\mathrm{CrO}_{3}$ treated coal for various coals

クロム酸イオンが石炭と反応するとき, カルボキシル基間で 生じるような比較的強い水素結合が解離していると思われる。 つまりクロム酸イオンは, 石炭構造内で形成されている水素 結合を部分的に破壞しながら反応していると推察される。 $3000 \sim 3600 \mathrm{~cm}^{-1}$ 領域の増加は, 水素結合の解離によって生じ た水酸基等が，クロム酸イオンと反応する一方，もう一方の 水酸基等は改めて水やアルコール，フェノール等と会合した ことによって生じたものと考えられる。あるいはクロム酸イ オンに水和した水が，クロム酸イオンとともに石炭中へ取り 込まれた可能性も考えられるが，詳細はよくわかっていない。

\section{3 石炭中の水酸基量とクロム酸反応量の関係}

石炭中に含まれる水酸基量を化学分析（アセチル化法）に より定量し, その水酸基量とクロム酸反応量の関係を評価し た。その結果をFig. 4 に示した。図中の白抜きプロットは系

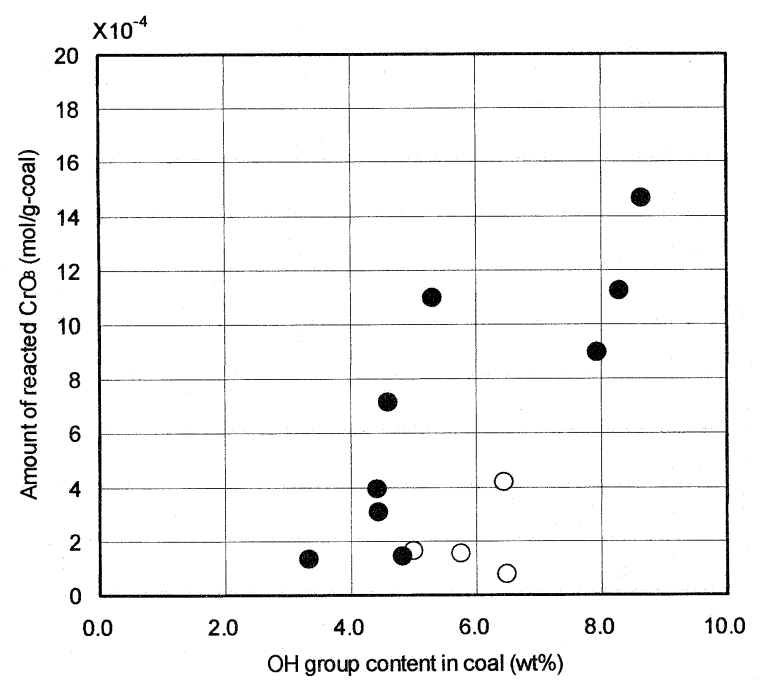

Fig. 4 Relationship between $\mathrm{OH}$ content and the amount of reacted $\mathrm{CrO}_{3}$ (Closed circles denote first group coals, Open circles denote second group coals, Experimental conditions : Sample quantity;2g, Reaction temperature; $323 \mathrm{~K})$
列 2 に属する石炭である。石炭中の水酸基量とクロム酸の反 応量には何らかの相関があるようだが，明確な関連性は認め られない。これは水酸基とクロム酸の反応が単に水酸基の量 的因子たけで決まるのではなく，その他の要因が影響してい ると思われる。すなわち本反応系において，クロム酸は石炭 中のすべての水酸基と反応するのではなく, 特定の環境に存 在する水酸基とのみ反応すると考えられる。そこでクロム酸 がどのような水酸基と反応しているのかを検討するため，石 炭のモデル化合物を用い検討した。

\section{4 各種フェノール類に対するクロム酸の反応性}

ここでは石炭中に含まれると考えられる含水酸基化合物の モデル物質として数種類のフェノールおよびアルコールを試 料とし, クロム酸反応量を測定した。Table 2にその結果を示 した。表中のデー夕は分子中に含まれる水酸基あたりのクロ 么酸反応量である。な扔サリチル酸はフェノール性水酸基と カルボキシル基の水酸基を有するが，クロム酸イオンがカル ボキシル基とは反応しないことを考慮し，水酸基の数を一つ として示してある。また他のカルボキシル基を有する化合物 についても同様の考え方にしたがった。

クロム酸との反応性は，モデル化合物の種類によって明ら かに異なる。一価フェノール類に対する反応性はいずれも低 い。前報で報告したように，一価フェノール類との反応は, 溶 液中のクロム酸初濃度に依存する。今回はクロム酸初濃度を 比較的低く抑えたために，反応性が低下したと考えられる ${ }^{17)} 。$ またベンジルアルコールは，他の一価フェノール類に比較す ればわずかに反応した。これはベンジルアルコールの一部が クロム酸により酸化されているためと考えられる。次に単環 系に水酸基を二つ持つ二価フェノール類は概ね反応性が高く， カテコールおよびその誘導体については，一つの水酸基につ

Table 2 Amount of reacted $\mathrm{CrO}_{3}$ for coal model compounds

\begin{tabular}{l|c|c|c}
\hline \multirow{2}{*}{ Model compounds } & \multirow{2}{*}{$\begin{array}{c}\text { Number } \\
\text { of OH }\end{array}$} & \multicolumn{2}{|c}{ Reacted $\mathrm{CrO}_{3}$ (mol/mol-OH) } \\
\cline { 3 - 4 } & group & 323 & 273 \\
\hline Phenol & 1 & 0.13 & - \\
o-Cresol & 1 & 0.11 & - \\
2, 6-Dimethylphenol & 1 & 0.04 & - \\
2-Naphtol & 1 & 0.17 & 0.13 \\
Salicylic acid & 1 & 0.36 & - \\
Benzyl alcohol & 1 & 0.55 & - \\
Catechol & 2 & 0.98 & 0.98 \\
3, 4-Dihydroxytoluene & 2 & 0.99 & 0.81 \\
3, 4-Dihydroxybenzoic & 2 & 0.91 & 0.77 \\
acid & & 0.35 & - \\
Biphenyl-2, 2'-diol & 2 & & - \\
2', 6'-Dihydroxy & 2 & 0.72 & - \\
acetophenone & & - & - \\
Alizarin & 2 & - & - \\
Purpurin & 3 & 0.75 & 0.58 \\
Pyrogallol & 3 &
\end{tabular}

- : no reaction 
きほほぼ一つのクロム酸イオンが反応することを見出した。す なわちカテコール分子とクロム酸イオンの反応比はほほ 1 ： 2 であることがわかった。ところが，構造中にキノン骨格を 有するアリザリンやプルプリンは, カテコール類似の構造を 有するにも関わらず，まったく反応しなかった。しかしなが らカルボニル基と水酸基との配置がアリザリンに類似してい る 2, 6-ジヒドロキシアセトフェノンに対しては, わずかに 反応した。これらの結果に対する詳細な理由は定かではない が, 分子軌道計算により, 水酸基の酸素原子上の電子密度を 計算したところ，キノン骨格は水酸基酸素の電荷密度を上げ る傾向が見出された。先述したようにクロム酸イオンと水酸 基の相互作用は水酸基酸素の電荷密度 (静電的陰性) が低い 状態のときに生じるようである。したがってクロム酸イオン と水酸基との反応は一概に化学量論的に決まるものではなく, 水酸基が結合している構造環境によって大きく変化すること が示唆された。

また分子中に水酸基を二つ有するものの, 一価フェノール 型構造を有するビフェニル-2, 2'-ジオールは, サリチル酸程 度の反応性にとどまった。すなわちクロム酸との反応にはカ テコールのように水酸基が隣接することが必要なのかもしれ ない。

\section{5 フェノールーアルコール混合系に対するクロム酸の反} 応性

石炭中に存在する水酸基は, IR スペクトルからもわかるよ うに, さまざまな石炭構造部位と相互作用しており, フリー な状態で存在するものはごくわずかであると考えられる。こ こでは, モデルとしてカテコール (フェノール) とベンジル アルコール（アルコール）の混合物を試料としてクロム酸水 溶液中に添加し, 性質の異なる水酸基の混合系に対するクロ ム酸反応性を検討した。なお，混合においては常に系内の全 水酸基量が一定となるように調整し, クロム酸との反応量も 単位水酸基あたりの反応量として算出した。その結果をFig. 5 に示した。プロットは反応時間20分以降, 定常状態となった データを平均したものである。クロム酸反応量は共存するア ルコール性水酸基量の増加に伴い減少した。この結果はあた かもクロム酸とアルコールの反応が進行せず，フェノールと の反応に対してのみ選択性を有するように見える。例えば石 炭中にカテコール型の構造が存在し, その水酸基に対してア ルコール性水酸基が水素結合等の相互作用していたとしても, クロム酸イオンはその水素結合を断ち, カテコール水酸基に のみ反応すると推察される。しかしながらアルコールのみの 時には少なくともその一部は反応することを確認している。 つまりカテコール型のようなフェノール類がアルコール性水 酸基と水素結合しているような場合, クロム酸はアルコール 性水酸基よりもフェノール性水酸基に対して優先的に反応す ると考えられる。

\section{6 反応温度の影響}

クロム酸水溶液中に有機物が混合した場合, どうしても酸

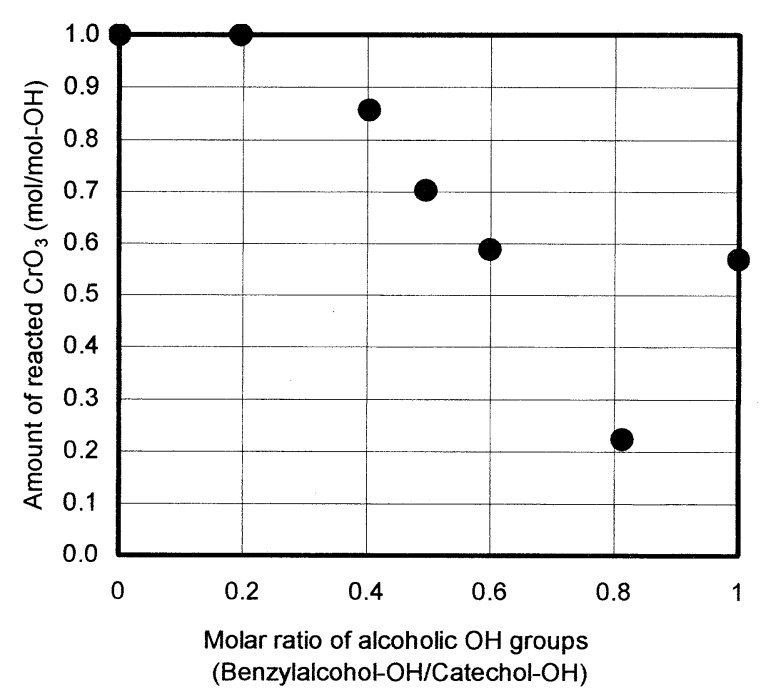

Fig. 5 Change of amount of reacted $\mathrm{CrO}_{3}$ for Catechol-Benzyl alcohol mixture (Experimental conditions : Initial $\mathrm{CrO}_{3}$ concentration;0.02mol/ $/ \mathrm{dm}^{3}$, Reaction temperature;323K)

化プロセスが関与することを考えなければならない。そこで 酸化反応をできるだけ抑える目的で, 反応温度を下げ実験を 試みた。Table 2 に試料として各種石炭モデル化合物を用い, 反応温度を $273 \mathrm{~K}$ とした場合のクロム酸反応量の結果を示し た。このときの溶液中に存在する三価のクロム酸量を確認し たところ，まったく確認されなかった。つまりクロム酸によ るフェノール類の酸化はほとんど進行していないと考えられ る。またTable 2よりカテコールおよびカテコール誘導体以外 のフェノール類は, 反応温度の低下に伴いほとんど反応しな くなることを見出した。また同様の反応条件下, カテコール ーフェノール混合系に対するクロム酸イオンの反応を試みた ところ, やはりカテコールのみが選択的に反応することがわ かった。以上の結果から，273K程度の温度領域では，ほとん どの場合カテコール型の水酸基のみが選択的にクロム酸イオ ンと反応すると予想され, 石炭とクロム酸との反応において も同様に, クロム酸イオンは石炭構造中のカテコール型水酸 基に対してのみ反応するのではないかと考えた。

\section{7 石炭中のカテコール型水酸基量の推定}

上記の結果を利用すれば，石炭中に存在するカテコール型 二価フェノールの水酸基量を概算できると考え, 各種石炭を 試料として先と同様の反応を試みた。初めにモデル化合物の 時と同様，本条件下でクロム酸による石炭の酸化反応の有無 を確認したところ，まったく進行しなかったことを確認した。 Table 3 には反応温度 $323 \mathrm{~K}$ と $273 \mathrm{~K}$ に扮ける各種石炭に対す るクロム酸の平衡反応量を示した。対象としたすべての石炭 において反応温度の低下はクロム酸反応量を低下させること がわかった。モデル化合物の結果に基づけば，273Kにおける 結果は, すべてカテコール型の二価フェノール類と考えるこ とができる。そこでこの結果をカテコール型二価フェノール 量とし，さらにアセチル化法により算出した水酸基量に対す る存在割合を算出し, Table 3に示した。特に太平洋炭と檸条 
Table 3 Estimation of Catechol type $\mathrm{OH}$ group in coals

\begin{tabular}{|c|c|c|c|c|}
\hline \multirow{3}{*}{ Coals } & \multirow{2}{*}{\multicolumn{2}{|c|}{ 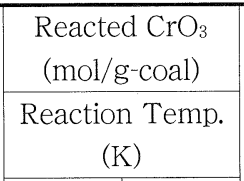 }} & \multirow{3}{*}{\begin{tabular}{|c|} 
Catechol \\
type $\mathrm{OH}$ \\
group \\
in coals* \\
(mol/g-coal)
\end{tabular}} & \multirow{3}{*}{$\begin{array}{c}\text { Catechol } \\
\text { type } \mathrm{OH} \\
\text { group } \\
\text { in coals* } \\
(\%)\end{array}$} \\
\hline & & & & \\
\hline & 323 & 273 & & \\
\hline Battleriver & $1.5 \mathrm{E}-03$ & $2.3 \mathrm{E}-04$ & $2.3 \mathrm{E}-04$ & 4.7 \\
\hline Wyoming & $1.1 \mathrm{E}-03$ & $1.2 \mathrm{E}-04$ & $1.2 \mathrm{E}-04$ & 3.8 \\
\hline Nakayama & $1.1 \mathrm{E}-03$ & $9.5 \mathrm{E}-04$ & $9.5 \mathrm{E}-04$ & 1.9 \\
\hline Illinois No. 6 & $4.2 \mathrm{E}-04$ & $5.0 \mathrm{E}-05$ & $5.0 \mathrm{E}-05$ & 1.3 \\
\hline Taiheiyo & $7.6 \mathrm{E}-05$ & 0 & 0 & 0 \\
\hline Neijyoto & $1.7 \mathrm{E}-04$ & & $3.9 \mathrm{E}-07$ & 0 \\
\hline
\end{tabular}

* These data were estimeted as that the reacted $\mathrm{CrO}_{3}$ at $273 \mathrm{~K}$ only reacted for dihydric phenols in coals.

塔炭は273Kではほとんど反応せず，カテコール型フェノール 類はほとんど存在しないものと思われる。それ以外の特にク ロム酸反応量が多い石炭については，石炭中の $1 \sim 4 \%$ 程度 存在することが予想された。しかしながらその含有量は全体 に少ないように思える。これはアセチル化法による水酸基の 定量はアルコール性水酸基やカルボキシル基の水酸基等をも 含むためと考えられる。また今回得られたカテコール型水酸 基量はバトルリバー炭が最も多く，最もクロム酸反応量が多 かった中山炭は約 $2 \%$ と比較的少なく，イリノイNo.6炭と同 程度であることが明らかとなった。この結果から，石炭構造 中のカテコール型フェノール類の存在は石炭に対するクロム 酸反応量に影響を与えるものの, 明確な相関は認められな かった。特に中山炭はバトルリバー炭やワイオミング炭に比 較して，カテコール型水酸基以外の高温領域（～323K）でク ロム酸と反応する水酸基の寄与が高いと考えられるが，その 正体は現段階では明らかではなく，今後の検討課題である。

\section{4. 結 言}

産地や石炭化度の異なる12種類の石炭に対しクロム酸を作 用させ，その反応量とその際に生じるIRスペクトル上の変化 との相関，あるいはアセチル化法により測定した石炭中の水 酸基量との相関について評価した。その結果以下の点を明ら かにすることが出来た。

(1)クロム酸イオンは低温 $(273 \mathrm{~K})$ で石炭中に存在するカテ コール型水酸基と選択的に反応する。

(2) カテコール型二価フェノール類に対するクロム酸イオン の反応量は水酸基とほぼ $1: 1$ で反応し，クロム酸反応 量が石炭中の二価フェノール類含有量を推定できること が示唆された。

本結果は簡単な操作により石炭中のフェノール性水酸基量 の存在形態を類推できる方法として期待できる。しかしなが ら，クロム酸とフェノール類との複合体（錯体）構造が不明 な点, 石炭構造中のキノン骨格近傍に水酸基が存在する場合, その量を把握できないこと，カテコール型水酸基以外にもク 口ム酸と比較的反応しやすい水酸基の存在が考えられること, 等問題点も多く，本法を石炭中のフェノール性水酸基の存在
形態の測定法として確立するためには更なる検討を必要とす る。

\section{文 献：References}

1) Van Krevelen, D. W., COAL (Elsevier), (1981)

2) Wiser, W. H., Proceedings of the Electric Power Research Institute Conference on Coal Catalysis, Palo Alto Carifornia, p. 3(1973)

3) Shinn, J. H., Fuel, 63 (9), 1187 (1984)

4）加藤隆，大内公耳，日工礻誌，71, 1193(1992) : Kato, T., Ouchi, K., J. Jpn. Inst. Energy, 71, 1193(1992)

5) Nakamura, K., Takanohashi, S., Sanada, Y., Energy \& Fuels, 9, 1003(1995)

6) Kovac, J., Larsen, J., W., Prepr. Am. Chem. Soc. Div. Fuel Chem., 22(5), 181(1977)

7) Given, P. H., Marzec, A., Barton, W.A., Lynch, L. J., and Gerstein, B. C., Fuel, 65, 155 (1986)

8) Iino, M., Fuel Proc. Tech., 62 (2000), 89-101

9) Schwager, L., Yen, T., Anal. Chem., 51 (4), 569-571 (1979)

10) Snape, C. E., Smith, C. A., Bartle, K. D., Matthews, R. S., Anal. Chem., 54 (1), 20-25 (1982)

11）細川正博，村田聡，野村正勝，石炭科学会議，35th, 79-82 (1998) : Hosokawa, M., Murata, S., Nomura, M., Conference of Coal Science, 35th, 79-82(1998)

12）米田昌広, 山西一誠, 相田哲夫, 石炭科学会議, 35th, 8790 (1998) : Yoneda, M., Yamanishi, K.,Aida, T., Conference of Coal Science, 35th, 87-90 (1998)

13）三浦孝一，前一広，草川拓已，石炭科学会議，35th, 271274(1998) : Miura, K., Mae, K., Kusakawa, T., Conference of Coal Science, 35th, 271-274(1998)

14) Miura K., Mae, K., Li, W., Kusakawa, T., Morozumi, F., Kumano, A., Energy \& Fuels, 15, 599-610 (2001)

15) Miura, K., Mae, K., Hasegawa, I., Chen, H., Kumano, A., Tanuma, K., Energy \& Fuels, 16, 23-31 (2002)

16) Murata, S., Hosakawa, M., Kidena, K., Nomura, M., Fuel Proc. Tech., 67, 231-243(2000)

17）古川茂樹, 岡田昌樹, 原田聡, 鈴木庸一, 日エネ誌, 80 (9), 835-842 (2001) : Furukawa, S., Okada, M., Harada, S., Suzuki, Y., J. Jpn. Inst. Energy, 80 (9), 835-842(2001)

18）三浦孝一，徐継軍，手銭雄太，永井裕久，橋本健治，燃協 誌，66, 264(1987) :Miura, K., Jyo, K., Tezeni, Y., Nagai, H., Hashimoto, K., Nenryo Kyokaishi, 66, 264(1987)

19）鈴木庸一，菅原素紀，穴沢一郎，分析化学，23,1137(1974)： Suzuki, Y., Sugawara, Y., Anazawa, I., Bunsekikagaku, 23, 1137 (1974)

20）畑見正男，大沢祥拡，杉村秀彦，燃協誌，46，819-827 (1957):Hatami, M., Osawa, Y., Sugimura, H., Nenryo Kyokaishi, 46, 819-827(1957)

21) Gu, G., Xu, Z., Nandakumar, K., Masliyah, J. H., Fuel, 81, 1859$1869(2002)$ 